\title{
INTERAKSI SOSIAL PADA MAHASISWA PESERTA MABINMABA 2017
}

\author{
Ninawati ${ }^{1}$, Monika ${ }^{2}$ \\ ${ }^{1}$ Fakultas Psikologi, Universitas Tarumanagara, Jakarta \\ Email: ninawati@mku.untar.ac.id \\ ${ }^{2}$ Fakultas Psikologi, Universitas Tarumanagara, Jakarta \\ Email: monika@fpsi.untar.ac.id
}

\begin{abstract}
There are many interactions among individuals in society. This research was attempted to describe the patterns of interaction among the "Mabinmaba" student. These patterns of interactions based on friendship, study, personal, and hobby of the students. The participant of this research consist of 120 students, they were separate in 4 groups. They were the student of the Faculty of Psychology. Purposive technique samling used in this research. The result of this research: there are qliques in these 4 groups. The networks based on pesonal issue had less in qlique liaison than the other networks.
\end{abstract}

Keywords: pattern of interactions, students, clique, network

\begin{abstract}
ABSTRAK
Ada banyak interaksi antar individu dalam masyarakat. Penelitian ini berusaha menggambarkan pola interaksi antara siswa "Mabinmaba". Pola interaksi ini didasarkan pada persahabatan, pembelajaran, pribadi, dan hobi para siswa. Partisipan dalam penelitian ini terdiri dari 120 siswa, mereka terpisah dalam 4 kelompok. Mereka adalah mahasiswa Fakultas Psikologi. Teknik purposive sampling digunakan dalam penelitian ini. Hasil penelitian ini: ada cliques di 4 kelompok ini. Jaringan yang didasarkan pada masalah personal memiliki hubungan yang lebih sedikit daripada jaringan lain.
\end{abstract}

Kata kunci: pola interaksi, siswa, klik, jaringan

\section{PENDAHULUAN}

Kegiatan sosial dapat dilakukan individu, baik dengan keluarganya maupun dengan orang-orang di luar keluarganya, teman atau masyarakat. Terutama pada mereka yang termasuk dalam kelompok usia remaja (antara 16-19 tahun). Pada dasarnya, manusia -- karena sebagai makhluk sosial - selalu membutuhkan sesamanya dan tidak dapat lepas dari hubungan dengan orang lain dalam berbagai macam kegiatan (Rakhmat, 2000).

Demikian halnya dengan mahasiswa, terutama sebagai mahasiswa yang baru diterima di sebuah perguruan tinggi, maka mereka pada umumnya perlu mencari relasi yang baru. Selain karena kebutuhan bersosialisasi sebagai makhluk sosial, kegiatan sebagai mahasiswa menuntut pula sosialisasi yang "ditugaskan" oleh fakultas, misalnya beberapa mata kuliah yang mengharuskan ada pekerjaan kelompok, diskusi kelompok dan beberapa kegiatan lainnya.

Sebagai mahasiswa baru yang berusia sekitar 17-19 tahun termasuk dalam kategori remaja, yang memiliki ciri-ciri sebagai berikut: a) kegelisahan, b) pertentangan, c) berkeinginan besar mencoba segala hal yang belum pernah diketahuinya, d) keinginan mencoba diarahkan ke diri sendiri maupun orang lain, e) ingin menjelajah ke alam sekitar yang lebih luas, f) berkhayal dan berfantasi, g) melakukan aktivitas berkelompok. Kondisi perasaan yang tidak berdaya terhadap dorongan-dorongan dari dalam diri mereka untuk bertindak, maupun terhadap kekangan dari luar berupa kekangan dari orang tua dan terbatasnya kebutuhan financial, acapkali melemahkan dan mematahkan semangat remaja. Dalam usaha mencari jalan keluar dari keadaan ini, kebanyakan remaja menemuka jalan keluar dengan berkumpul dengan teman melakukan kegiatan bersama, mengadakan penjelajahan serta berkelompok (Gunarsa \& Gunarsa, 2009).

Berdasarkan kebutuhan tersebut maka para mahasiswa akan memiliki interaksi dengan sesama mahasiswa lainnya. Shaffer (1994) menjelaskan tentang peranan teman sebaya kepada remaja 
sebagai berikut: a) teman sebaya sebagai penguat sosial, b) teman sebaya sebagai model tingkah laku remaja, c) teman sebaya sebagai obyek dalam perbandingan sosial, dan d) teman sebaya sebagai pengkritik dan agen untuk meyakinkan anggotanya.

Dalam perkuliahan tentunya para mahasiswa terlibat dalam berbagai interaksi sesuai dengan informasi yang dipertukarkan. Begitu juga ketika berinteraksi (berhubungan) dengan sesama mahasiswa. Menurut Rogers dan Kincaid (1981), hubungan atau interaksi yang dilakukan secara terus menerus, pada gilirannya akan mengakibatkan terjadinya jaringan.

Menurut Myers (2010: 394), di Psikologi Sosial dikenal apa yang disebut "need to belong". Yakni, kebutuhan manusia untuk menjalin hubungan dengan orang lain. Kebutuhan ini merupakan porsi terbesar dalam hidup manusia. Lebih lanjut Myers menyatakan, kepuasan dalam need to belong berhubungan dengan dua kebutuhan manusia lainnya. Yakni, perasaan otonom dan kompetens. Myers juga menyatakan, salah satu unsur kebahagiaan - selain feeling free dan feeling capable - adalah feeling connected.

Namun menurut Roger dan Kincaid (1981), tidak mungkin seseorang menjalin hubungan dengan semua orang. Umumnya, hubungan (hanya) akan terjalin antara individu dengan sejumlah orang tertentu saja, sementara dengan yang lainnya, tidak. Banyak faktor yang menyebabkannya. Salah satunya, faktor kepribadian.

Rogers (dikutip oleh Hjelle \& Zieger, 1981) mengatakan, jika seseorang semakin menerima dirinya sendiri, ia akan semakin menerima orang lain. Supratiknya (1995) juga menyatakan, semakin besar penerimaan diri seseorang, akan semakin besar pula penerimaannya pada orang lain. Ini akan semakin memudahkan dalam melestarikan dan memperdalam hubungan dengan orang lain.

Bisa juga terjadi, sebagaimana dikatakan Baron et al. (2014: 241), karena adanya faktor kesamaan (misalnya, status sosial ekonomi) dan proksimitas (kedekatan jarak fisik), maka seseorang lebih berkemungkinan menjalin hubungan dengan orang tertentu tapi tidak dengan yang lain.

Selanjutnya, jika hubungan (interaksi) seseorang dengan lainnya berlangsung relatif teratur, maka akan terbentuklah jaringan antara orang-orang tersebut (Hargie \& Dickson, 2004). Soderstrom menyatakan, suatu jaringan terdiri dari sejumlah aktor yang saling berhubungan lewat hubungan langsung maupun tak langsung. Aktor di sini bisa macam-macam. Ia bisa individu, tim, organisasi dan lain sebagainya. Yang jelas, bagi Soderstrom mengamati posisi aktor dalam jaringan adalah menarik. Pasalnya, menurutnya, posisi tersebut bisa saja terkait dengan kekuasaan, kesuksesan, pengetahuan dll dari aktor-aktornya. Bagi Rogers dan Kincaid, jaringan bisa diamati di berbagai tingkatan. Bisa di tingkat sistem, klik, dyadic, atau posisi individual aktornya (bridge, liaison, isolate). Selain itu, jaringan juga bisa dilihat dari polanya. Misalnya, luas/sempit, terbuka/tertutup, terpecah/utuh dan lainnya.

Group adalah kumpulan orang-orang yang memiliki kesamaan (with something in common) Umumnya grup terdiri dari orang-orang yang memiliki kepentingan atau karakteristik yang sama dan secara periodik melakukan sesuatu yang sama. Besar grup ada yang mengatakan anggotanya minimal half a dozen. Tetapi ada yang mengatakan dua orang (dyad) bisa juga disebut grup (Baumeister \& Bushman, 2014).

Shaw (1981) menyatakan, ada suatu ciri dalam semua grup. Yakni, anggota-anggotanya saling berinteraksi. Karenanya, Shaw mendifinisikan grup adalah dua orang atau lebih yang berinteraksi dan saling mempengaruhi satu dengan yang lainnya. Suatu grup terdiri dari dua orang atau lebih yang berinteraksi lebih dari sekejab (dalam waktu yang relatif lama), saling mempengaruhi melalui cara-cara tertentu (Myers, 2010).

Posisi individu dalam jaringan berhubungan perilakunya. Tsai (2001) menemukan bahwa semakin sentral posisi seseorang dalam jaringan maka akan semakin inovatif. Lin (2017) 
menyatakan, posisi individu dalam jaringan berhubungan dengan modal sosial (social capital) seseorang. Demikian pula yang ditemukan oleh Sparrowe, Liden, Wayne dan Kraimer (2001), posisi seseorang dalam jaringan berkaitan dengan performansi perannya. Sementara itu, hasil penelitian Borgatti dan Foster (2003) menyatakan bahwa jenis hubungan jaringan yang berbeda memiliki fungsi yang berbeda pula.

Pertanyaannya, apakah ada perbedaan jaringan di antara mahasiswa peserta kegiatan mabinmaba? Pada jaringan apakah mahasiswa banyak terlibat? Apakah mahasiswa yang terlibat dalam jaringan tertentu juga terlibat pada jaringan yang lain? Sedikit atau banyak, pertanyaan itu kemudian menjadi salah satu alasan mengapa penelitian ini dilakukan.

\section{METODE PENELITIAN}

Desain penelitian ini adalah kuantitatif deskriptif. Partisipan dalam penelitian ini adalah mahasiswa Fakultas Psikologi angkatan tahun akademik 2017/2018. Partisipan dipilih berdasarkan purposive technique sampling, yaitu empat kelompok mahasiswa dengan masingmasing kelompok berjumlah 30 orang.

Pengumpulan data dilakukan melalui kuesioner yang terdiri dari empat bagian. Pertama, pengantar. Kedua inform consent. Ketiga identitas partisipan terdiri dari nama, kelas, usia, hobby, alasan memilih program studi Psikologi. asal sekolah (kota). Keempat, pilihan hubungan partisipan ketika ia berbicara/bertanya tentang masalah "perkuliahan" dan masalah pribadi. Partisipan diminta memilih maksimal tiga nama sesama peserta kuliah yang terdaftar, nama peserta kuliah disertakan pada lembar kuesioner.

Penyebaran kuesioner dilakukan pada tanggal 13 September 2017, pada saat bimbingan PA. Pengisian kuesioner memerlukan waktu antara 10-15 menit. Pengisian kuesioner dilakukan di dalam kelas bersama-sama dan dikumpulkan pada saat itu juga. Setelah diisi lengkap, kuesioner dikumpulkan kembali untuk dianalisis.

Analisis data dilakukan tiga tahap. Pertama, untuk mengetahui pola jaringan di tingkat sistem dipergunakan (1). Sosiogram, dan (2). Tingkat keterhubungan. Kedua, untuk mengetahui pola jaringan di tingkat klik dipergunakan (1). Sosiogram. (2). Tingkat keterhubungan antarklik. Ketiga, untuk mengetahui pola kepemukaan pendapat dipergunakan (1). Sosiogram; (2). Tingkat hubungan kepemukaan pendapat.

\section{HASIL dan PEMBAHASAN}

Partisipan penelitian ini berjumlah 120 orang, yang terdiri dari empat kelompok. Pengelompokkan dilakukan berdasarkan kelompok mahasiswa dalam proses Pembimbingan Akademik yang difasilitasi oleh satu orang dosen. Masing-masing kelompok terdiri dari 30 orang mahasiswa yang teregistrasi pada tahun akademik 2017/2018.

Dalam penelitian ini dua kelompok akan dijadikan sebagai kelompok uji dan dua kelompok lainnya sebagai kelompok kontrol. Penelitian ini sebagai penelitian awal disampaikan secara deskriptif jaringan yang terbentuk dari empat kelompok yang semuanya belum diberikan intervensi. Dari 120 partisipan, 5 orang mahasiswa tidak hadir yaitu dua orang pada kelompok 4 dan tiga orang pada kelompok 4.

Pada kelompok 1 terdapat 5 klik pada interaksi antarteman, 3 klik pada interaksi tentang perkuliahan, 4 klik pada interaksi masalah pribadi, dan 6 klik pada interaksi hobby. Penghubung klik tidak ditemukan pada interaksi perkuliahan, ada 4 orang sebagai penghubung klik pada interaksi antarteman, 2 orang pada interaksi masalah pribadi, dan 5 orang pada interaksi hobby. Pemuka pendapat (opinion leader), masing-masing ada 2 orang pada interaksi antarteman, dan perkuliahan; sedangkan pada interaksi masalah pribadi dan hobby tidak terdapat pemuka pendapat. Pemencil (isolate) pada interaksi antarteman ada satu orang, interaksi perkuliahan ada 2 orang, pada interaksi masalah pribadi ada 8 orang, dan pada interaksi hobby ada 5 . 
Tabel 1.

Pola Interaksi pada Kelompok 1 dan Kelompok 2

\begin{tabular}{llcccccccc}
\hline No. & Indikator & \multicolumn{4}{c}{ Kelompok 1 } & \multicolumn{5}{c}{ Kelompok 2 } \\
\hline & teman & perkuliahan & $\begin{array}{c}\text { masalah } \\
\text { pribadi }\end{array}$ & hobi & teman & perkuliahan & $\begin{array}{c}\text { masalah } \\
\text { pribadi }\end{array}$ & hobi \\
\hline 1. & Jumlah klik & 5 & 3 & 4 & 6 & 5 & 3 & 2 & 3 \\
2. & $\begin{array}{l}\text { Penghubung } \\
\text { klik (orang) }\end{array}$ & 4 & -- & 2 & 5 & 7 & 2 & -- & -- \\
3. & 2 & 2 & -- & -- & 5 & 2 & -- & 1 \\
$\begin{array}{l}\text { Pemuka } \\
\text { pendapat*) } \\
\text { (orang) } \\
\text { Isolate } \\
\text { (orang) }\end{array}$ & 1 & 2 & 8 & 5 & -- & 3 & 13 & 6 \\
\hline
\end{tabular}

Keterangan: *) dipilih oleh lima orang atau lebih

Pada kelompok 2 terdapat 5 klik pada interaksi antarteman, 3 klik pada interaksi tentang perkuliahan, 2 klik pada interaksi masalah pribadi, dan 3 klik pada interaksi hobby. Penghubung klik tidak ditemukan pada interaksi masalah pribadi dan hobby, ada 7 orang sebagai penghubung klik pada interaksi antarteman, 2 orang pada interaksi perkuliahan. Pemuka pendapat (opinion leader), ada 5 orang pada interaksi antarteman, dan 2 orang pada interaksi perkuliahan, 1 orang pada interaksi hobby; sedangkan pada interaksi masalah pribadi tidak terdapat pemuka pendapat. Pemencil (isolate) pada interaksi antarteman tidak ada pemencil, interaksi perkuliahan ada 3 orang, pada interaksi masalah pribadi ada 13 orang, dan pada interaksi hobby ada 6 orang. Data selengkapnya dapat dilihat pada tabel 1 .

Pada kelompok 3 terdapat 4 klik pada interaksi antarteman, 3 klik pada interaksi tentang perkuliahan, 2 klik pada interaksi masalah pribadi, dan 4 klik pada interaksi hobby. Penghubung klik ditemukan masing-masing 6 orang pada interaksi antar teman dan perkuliahan, tidak ada penghubung klik pada interaksimasalah pribadi, 3 orang pada interaksi hobby. Pemuka pendapat (opinion leader), ada 3 orang pada interaksi antarteman, dan masing-masing 1 orang pada interaksi perkuliahan, interaksi masalah pribadi dan pada interaksi hobby. Pemencil (isolate) pada interaksi antarteman ada 5 orang, interaksi perkuliahan ada 4 orang, pada interaksi masalah pribadi ada 13 orang, dan pada interaksi hobby ada 7 orang.

Pada kelompok 4 terdapat 4 klik pada interaksi antarteman, 3 klik pada interaksi tentang perkuliahan, 3 klik pada interaksi masalah pribadi, dan 3 klik pada interaksi hobby. Penghubung klik ditemukan masing-masing 2 orang pada interaksi antarteman dan perkuliahan, tidak ada penghubung klik pada interaksi masalah pribadi, 2 orang pada interaksi hobby. Pemuka pendapat (opinion leader), ada 4 orang pada interaksi antarteman, dan masing-masing 1 orang pada interaksi perkuliahan dan pada interaksi hobby, sedangkan pada interaksi masalah pribadi ada 2 orang. Pemencil (isolate) pada interaksi antarteman tidak ada pemencil, interaksi perkuliahan ada 4 orang, pada interaksi masalah pribadi ada 13 orang, dan pada interaksi hobby ada 9 orang. Data selengkapnya dapat dilihat pada tabel 2 berikut. 
Tabel 2.

Pola Interaksi pada Kelompok 3 dan Kelompok 4

\begin{tabular}{|c|c|c|c|c|c|c|c|c|c|}
\hline No. & Indikator & & Kelomp & & & & Kelomp & & \\
\hline & & teman & perkuliahan & $\begin{array}{l}\text { masalah } \\
\text { pribadi }\end{array}$ & hobi & teman & perkuliahan & $\begin{array}{c}\text { masalah } \\
\text { pribadi }\end{array}$ & hobi \\
\hline 1. & Jumlah klik & 4 & 3 & 2 & 4 & 4 & 3 & 3 & 3 \\
\hline 2. & $\begin{array}{l}\text { Penghubung } \\
\text { klik (orang) }\end{array}$ & 6 & 6 & -- & 3 & 2 & 2 & -- & 2 \\
\hline 3. & $\begin{array}{l}\text { Pemuka } \\
\text { pendapat*) } \\
\text { (orang) }\end{array}$ & 3 & 1 & 1 & 1 & 4 & 1 & 2 & 1 \\
\hline 4. & $\begin{array}{l}\text { Isolate } \\
\text { (orang) }\end{array}$ & 5 & 4 & 13 & 7 & -- & 4 & 13 & 9 \\
\hline
\end{tabular}

Keterangan: *) dipilih oleh lima orang atau lebih

\section{KESIMPULAN dan SARAN Kesimpulan}

Semua kelompok, jaringannya tidak terintegrasi dalam empat hubungan yang diteliti. Penghubung antarklik paling sedikit adalah pada interaksi masalah pribadi, demikian pula halnya dengan interaksi pada hobby.

Pada interaksi antarteman lebih banyak kliknya daripada perkuliahan, hal ini dapat terjadi karena dalam kondisi perkuliahan mungkin saja para mahasiswa terbentuk kelompok kerja dalam pengerjaan tugas. Dalam hal ini dapat dikatakan setiap mahasiswa menunjukkan performansi perannya, seperti dikatakan Sparrowe, et al. (2001), posisi seseorang dalam jaringan berkaitan dengan performansi perannya.

Pada interaksi sosial perkuliahan lebih sedikit kliknya dibandingkan antarteman. Isolate pada hubungan interaksi perkuliahan lebih sedikit daripada tindakan yang lain. Dengan membandingkan interaksi perkuliahan dan hubungan antarteman, dapat dikatakan jika berbicara atau memiliki teman maka mahasiswa akan membentuk klik lebih banyak, tetapi dalam urusan perkuliahan kliknya lebih sedikit artinya mereka bisa bergabung dengan teman dari klik lain. Ketika seseorang membentuk klik dalam suatu jaringan maka akan memiliki fungsi yang berbeda sejalan dengan hasil penelitian Borgatti dan Foster (2003) yang menyatakan bahwa jenis hubungan jaringan yang berbeda memiliki fungsi yang berbeda pula.

Pemuka pendapat pada interaksi perkuliahan terlalu sedikit, padahal sebaiknya pemuka pendapatnya lebih banyak karena diharapkan pemuka pendapat dapat sebagai leader (tempat bertanya). Pemuka pendapat adalah posisi sentral yang seharusnya merupakan posisi penting seperti dikemukan oleh Tsai (2001) bahwa semakin sentral posisi seseorang dalam jaringan maka akan semakin inovatif.

\section{Saran}

Penelitian ini merupakan penelitian awal yang menggambarkan interaksi sosial mahasiswa angkatan 2017/2018 peserta Mabinmaba yang menggambarkan pola jaringan dalam hubungan 
antarteman, perkuliahan, masalah pribadi, dan hobby. Dalam kegiatan Mabinmaba yang mendapat pendampingan dari para mentor yaitu mahasiswa senior dan fasilitator para dosen Penasehat Akademik, kiranya perlu dilihat kembali setelah masa bimbingan selama satu semester. Untuk itu, penelitian ini selayaknya dilanjutkan dengan program intervensi yang diberikan kepada mahasiswa tersebut kemudian digambarkan kembali pola jaringannya.

\section{UCAPAN TERIMA KASIH.}

Ucapan terima kasih disampaikan kepada para partisipan mahasiswa yang terlibat dalam penelitian ini. Selain itu terima kasih kepada Direktorat Penelitian dan Pengabdian kepada Masyarakat Universitas Tarumanagara yang menyediakan dana penelitian, serta pihak-pihak yang mendukung pelaksanaan penelitian ini.

\section{REFERENSI}

Baumeister, R.F., \& Bushman, B.J. (2014). Social psychology and human nature (3rd ed.). New York: Wadsworth, Cengage Learning.

Borgatti, S.P., dan Foster, P.C. (2003). The network paradigm in organizational research: A review and typology. Journal of Managemen. 29, (6). 991-131.

Buku Panduan Masa Pembinaan Mahasiswa Baru (2017). Jakarta: Fakultas Psikologi Universitas Tarumanagara.

Effendi (1993). Ilmu, teori dan filsafat komunikasi. Bandung: Cipta Aditya Bakti.

Gunarsa \& Gunarsa (2009). Psikologi remaja. Jakarta: Gunung Mulia.

Hargie, O. \& Dickson, D. (2004). Skilled interpersonal communication: Research, theory \& practice (4th ed.), New York, NY: Routledge Taylor \& Francis Group.

Hjelle, L.A. \& Ziegler, D.J. (1981). Personality theories: Basic assumptions, research and application ( $2^{\text {nd }}$ editon). Singapore: McGraw-Hill Book Co.

Lin, N. (2017). Building a network theory of social capital. London: Routledge.

Muijs, D \& Reynolds, D (2011). Effective teaching: Evidence and practice. London: Sage.

Myers, D.G. (2010). Social psychology (10 ${ }^{\text {th }}$ edition). Boston: McGraw-Hill.

Ormrod, J.E. (2009). Psikologi pendidikan: Membantu siswa tumbuh dan berkembang. Edisi Keenam. Jilid 2. Jakarta: Erlangga.

Rakhmat (2000). Psikologi komunikasi. Bandung: Remaja Rosdakarya Offset.

Rogers, E.M. \& Kincaid, D. (1981). Communication network, toward a new paradigm for research. New York: The Free Press.

Santrock, J.W. (2011). Educational psychology. (5th ed). New York: McGraw Hill.

Schunk, D.H. (2014). Learning theories an educational perspective. (6th ed). New York: Pearson.

Shaffer, D.R. (1994) Social and personality development ( $3^{\text {rd }}$ ed). California: Broks.

Soderstrom, S.B. Social Psychology of Networks: Influence of Emotion on Perception of Personal and Professional Networks, https://www.kellogg.northwestern.edu/research/ktag/images/KJOB05\%20Sara\%20Soderst rom.pdf

Sparrowe, R.T., Liden, R.C., Wayne, S.J., dan Kraimer, M.L. (2001). Social networks and the performance of individuals and groups. Academy of Management Journal.

Supratiknya, A. (1995). Komunikasi antarpribadi tinjauan psikologis. Yogyakarta: Kanisius. 
Tsai, W. (2001). Knowledge transfer in intraorganizational networks: Effects of network position and absorptive capacity on business unit innovation and performance. The Academy of Management Journal, 44(5), 996-1004.

Wasserman, S. \& Faust, K. (1999). Social network analysis: Methods and applications. New York: Cambridge University Press.

\section{Sosiogram 1. Interaksi antarteman dari Kelompok 1}

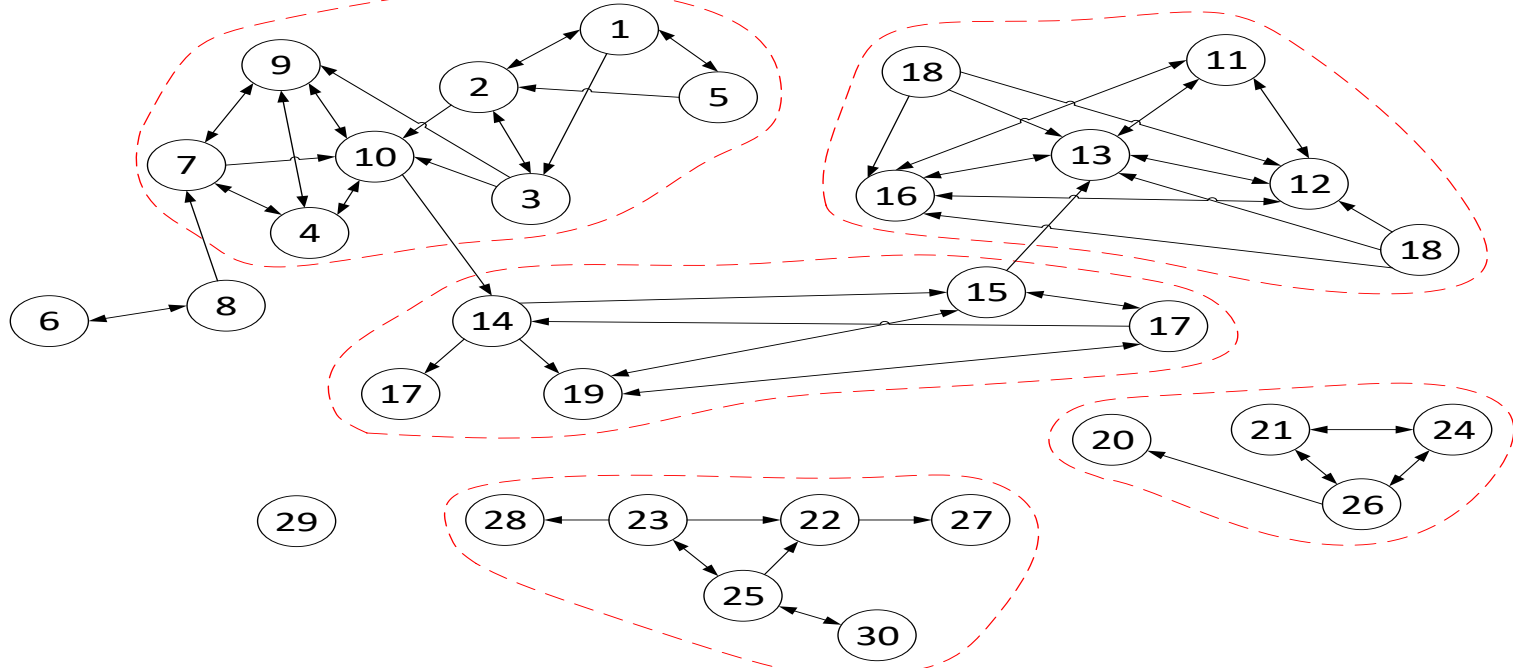

\section{Sosiogram 2. Interaksi antarteman dari Kelompok 2}

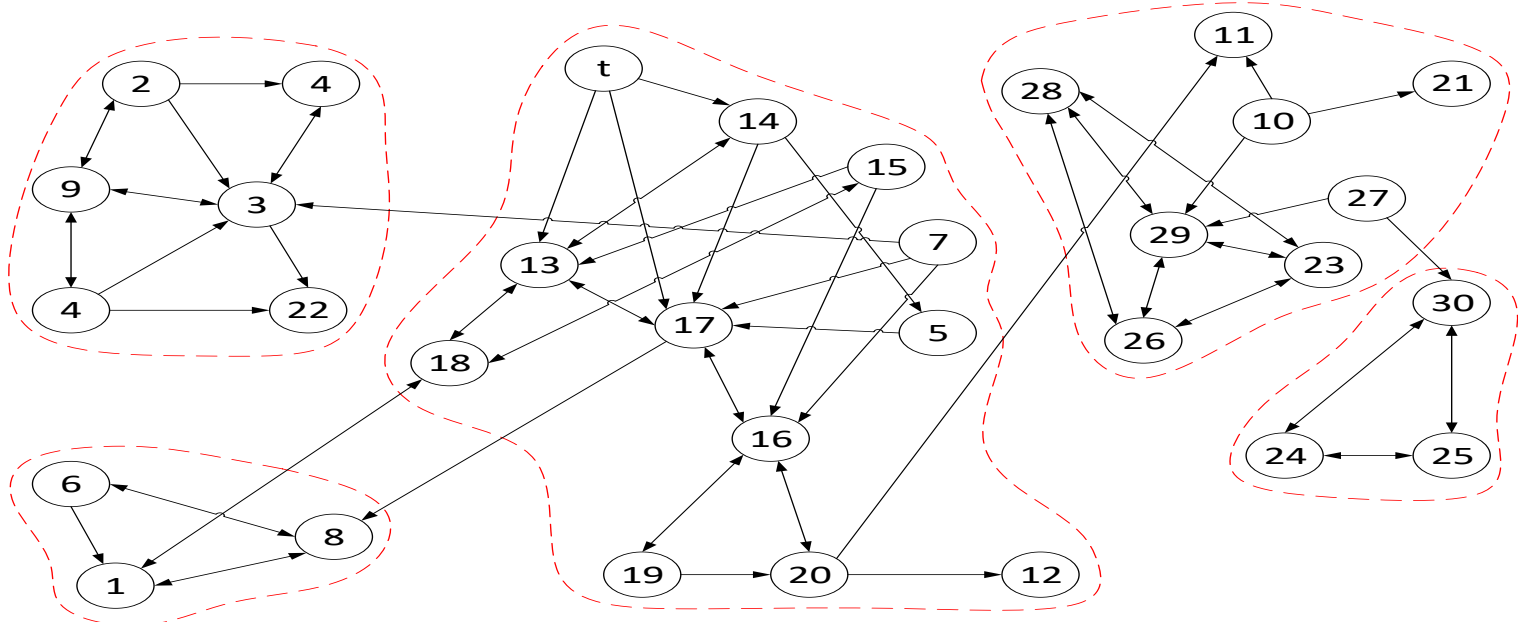

\section{Sosiogram 3. Interaksi tentang pembahasan perkuliahan dari kelompok 1}

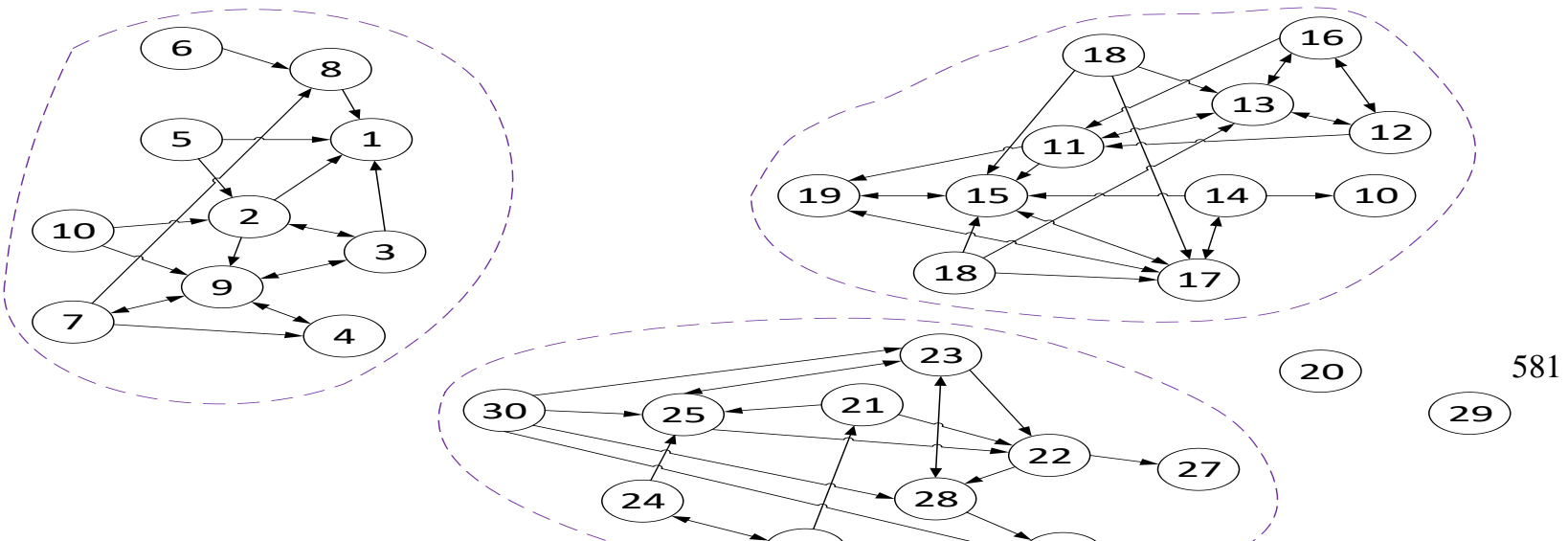


Sosiogram 4. Interaksi tentang pembahasan perkuliahan dari kelompok 2

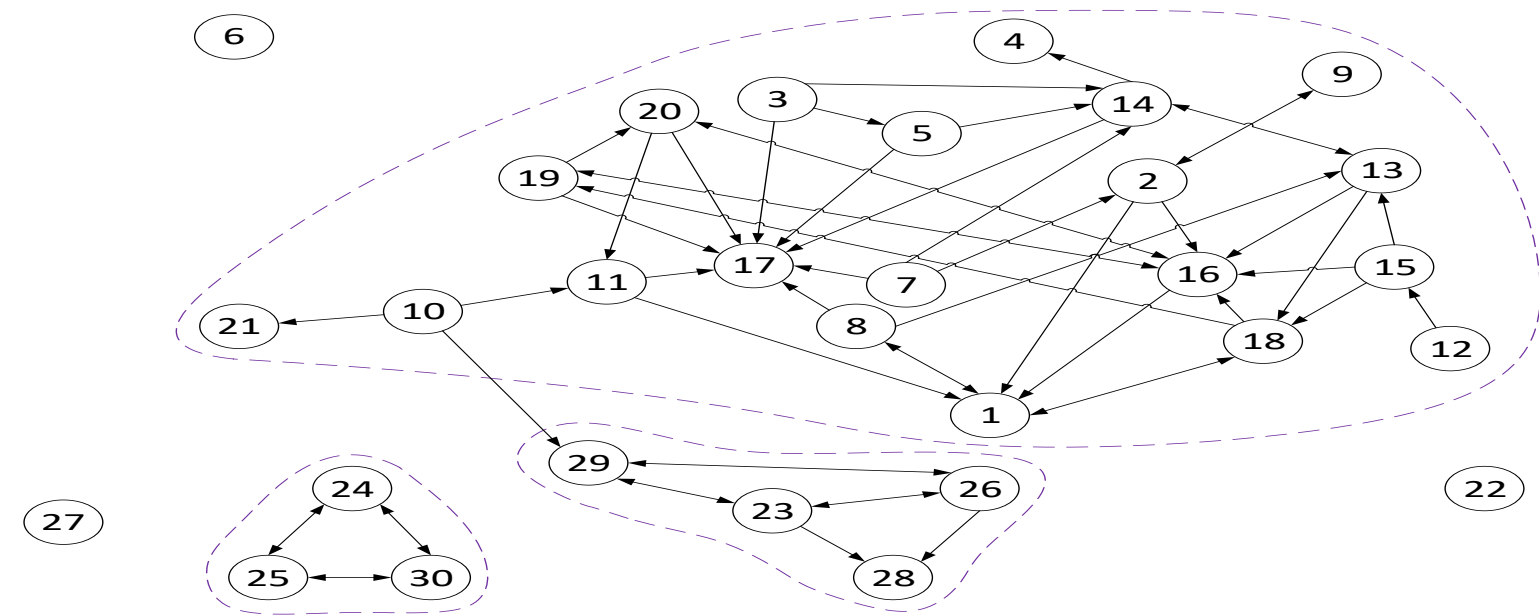

Sosiogram 5. Interaksi tentang pembahasan masalah pribadi dari kelompok 1

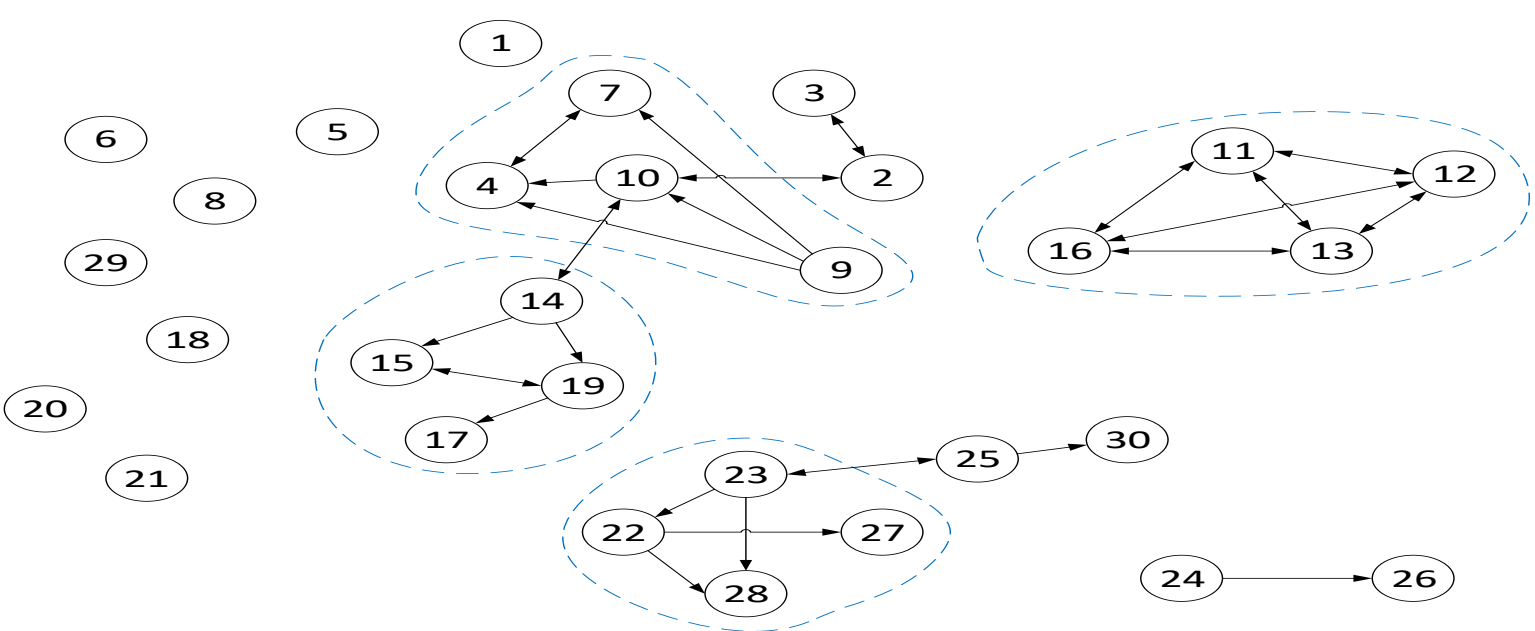

Sosiogram 6. Interaksi tentang pembahasan masalah pribadi dari kelompok 2

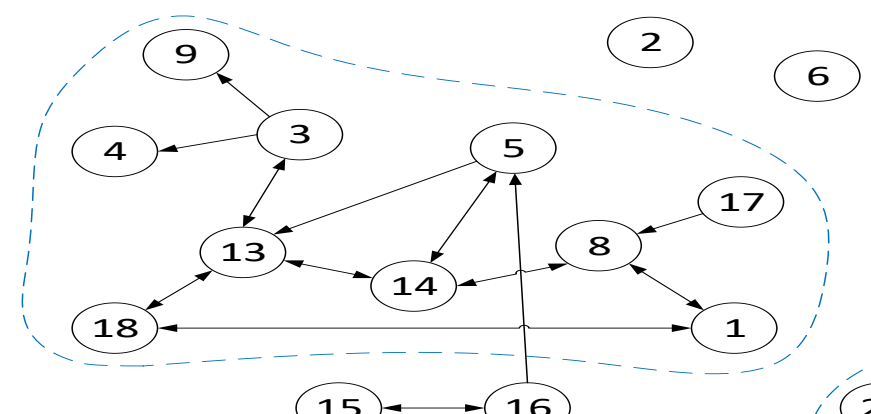

(19)
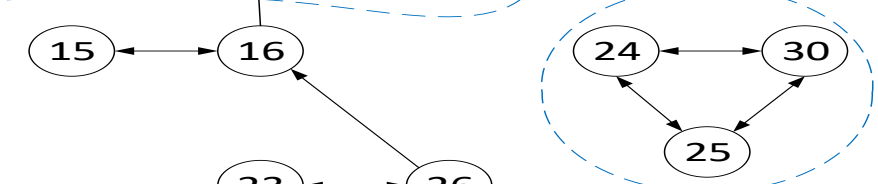
Sosiogram 7. Interaksi tentang hobi dari kelompok 1

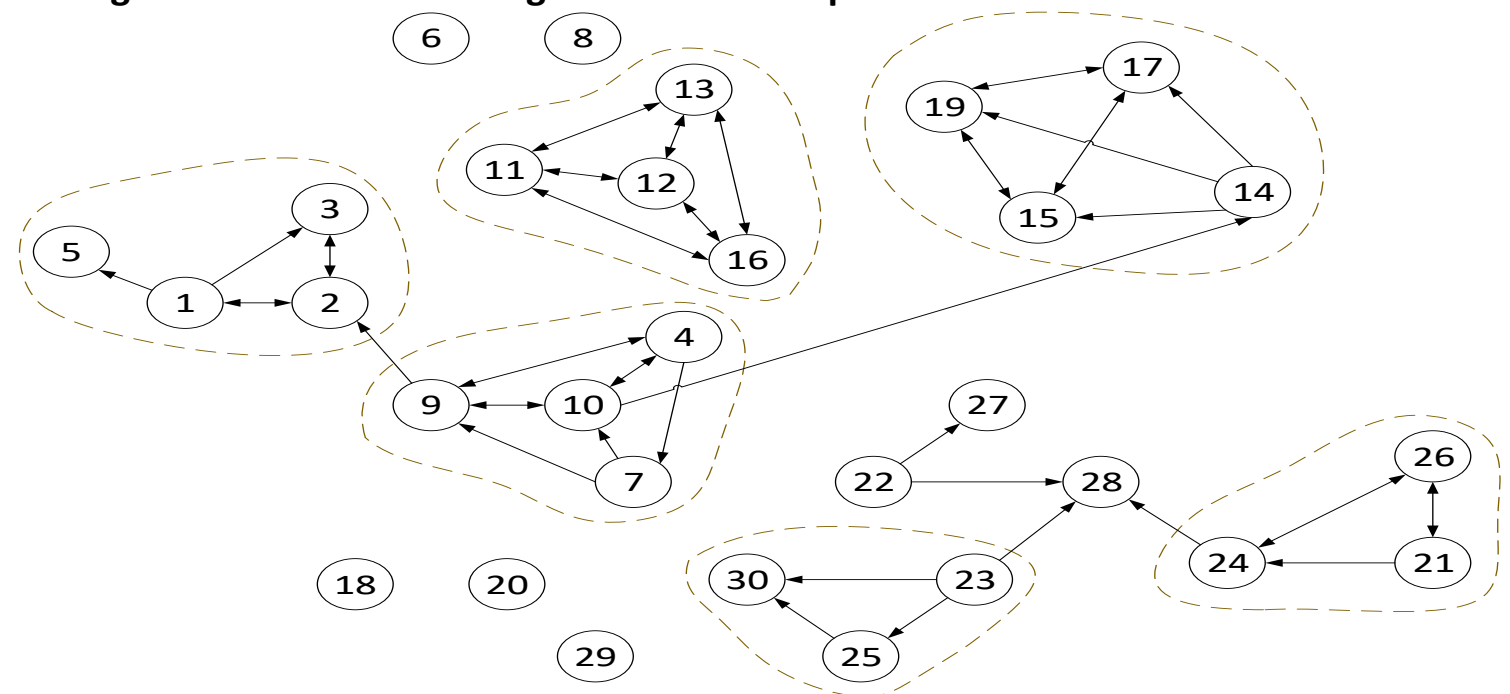

Sosiogram 8. Interaksi tentang hobi dari kelompok 2

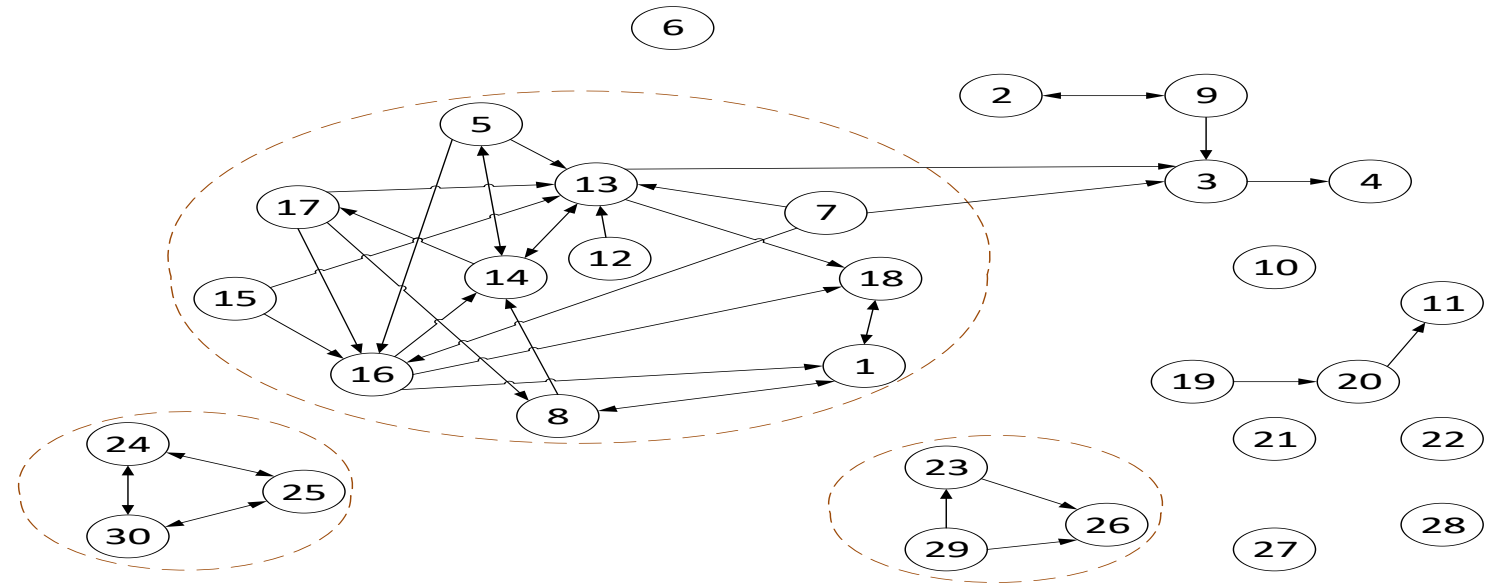



Sosiogram 9. Interaksi antarteman dari Kelompok 3

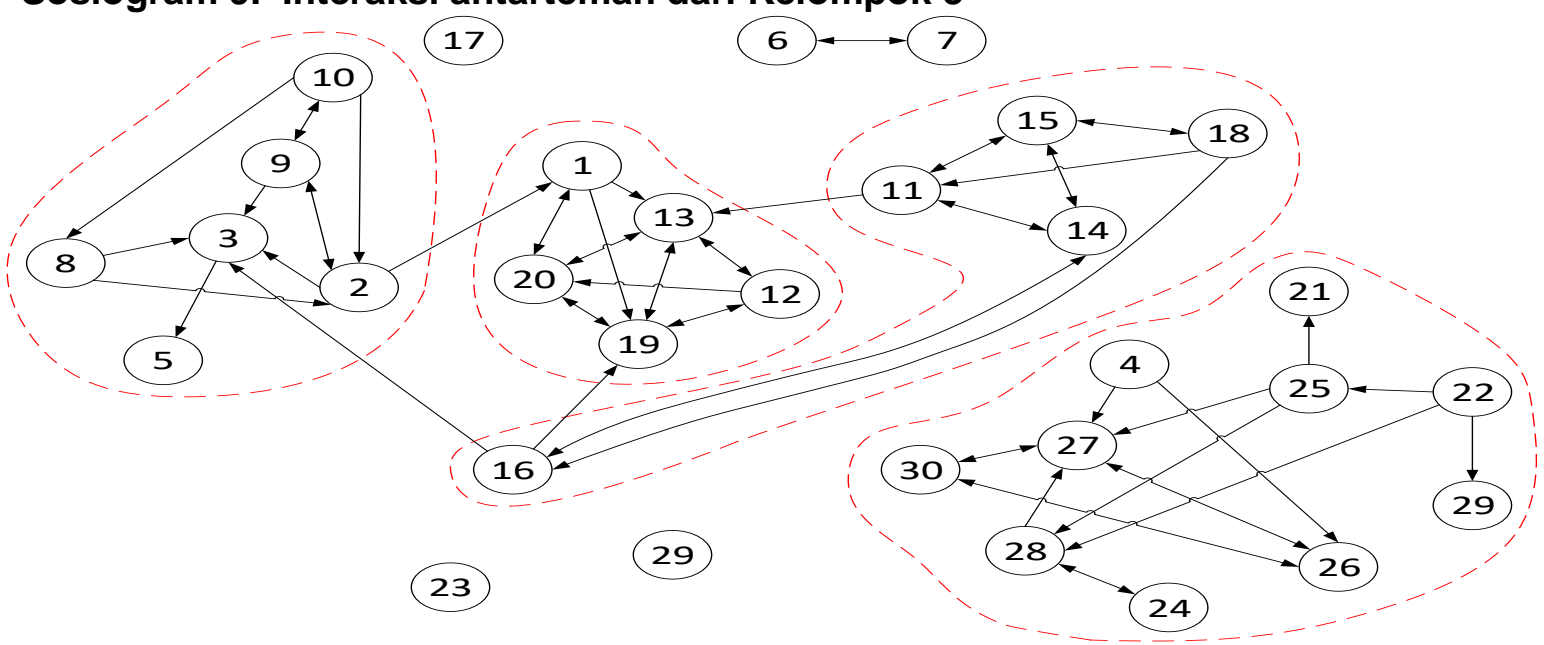

Sosiogram 10. Interaksi antarteman dari Kelompok 4
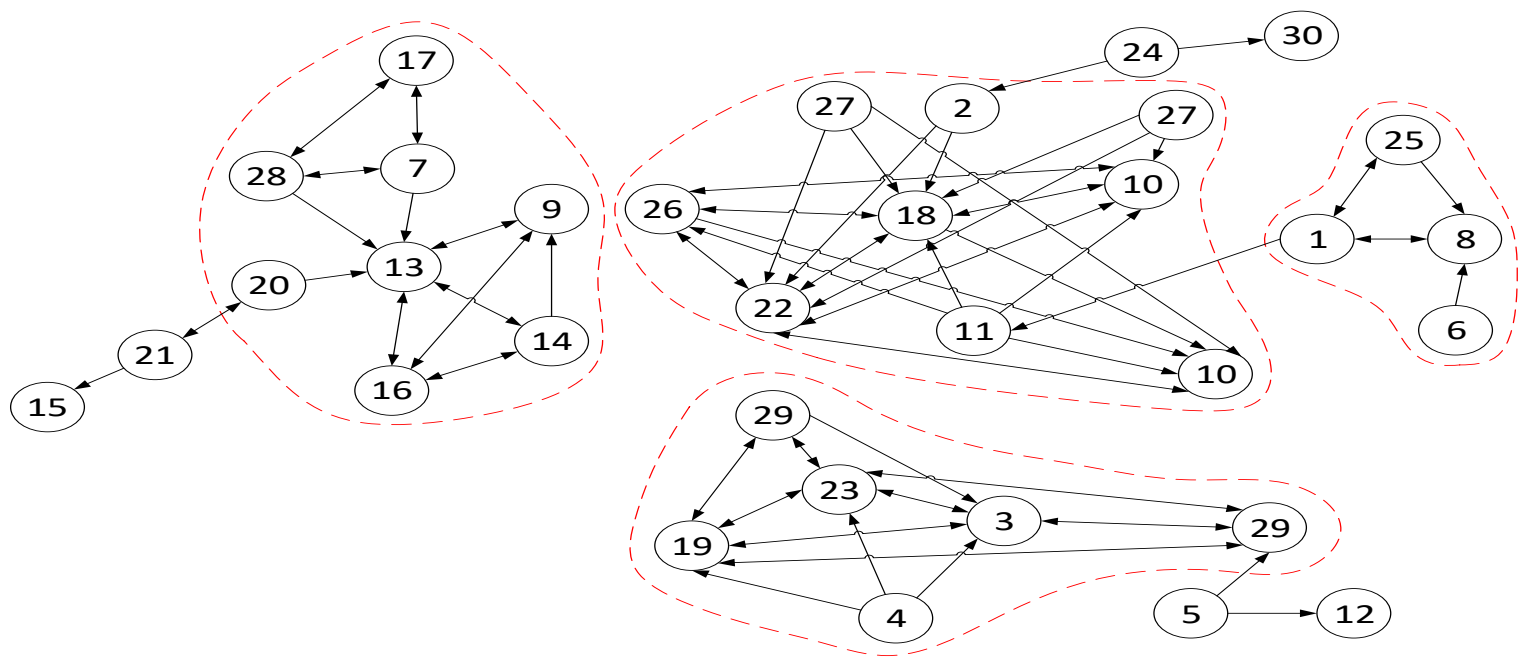

Sosiogram 11. Interaksi tentang pembahasan perkuliahan dari kelompok 3

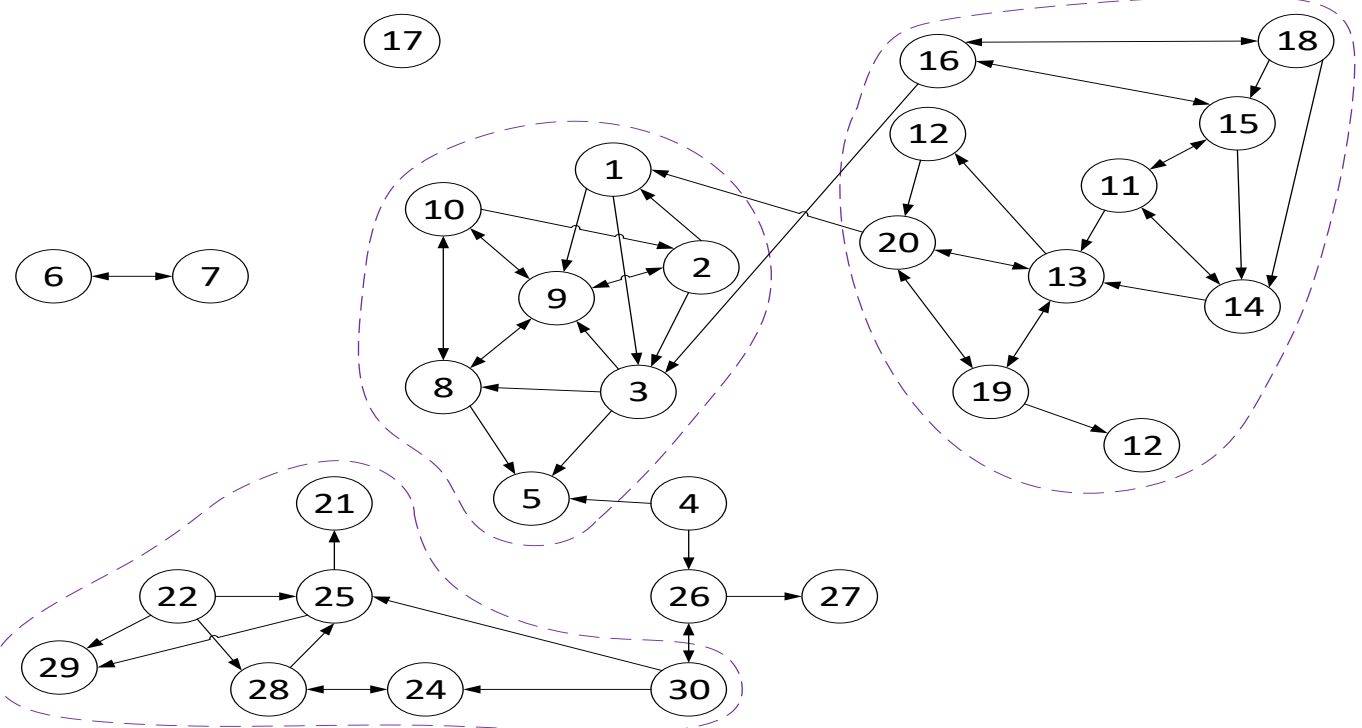


Sosiogram 12. Interaksi tentang pembahasan perkuliahan dari kelompok 4

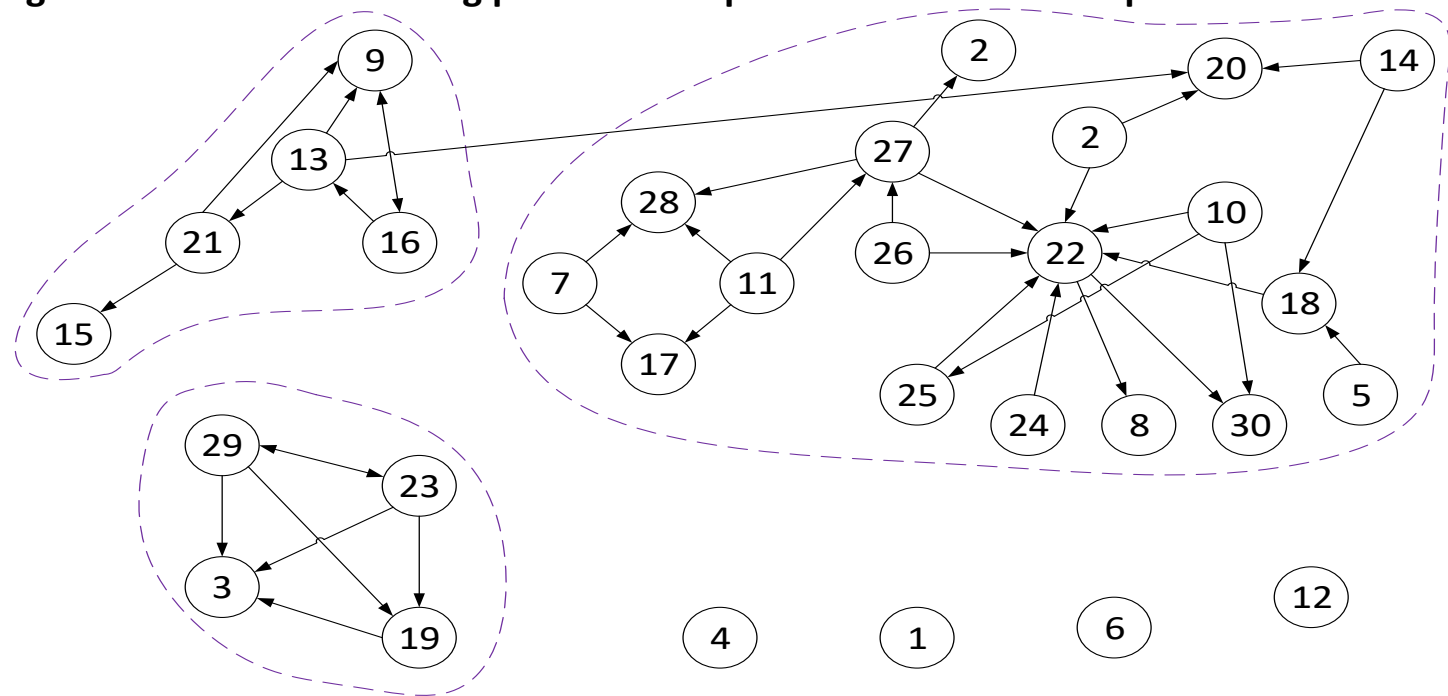

Sosiogram 13. Interaksi tentang pembahasan masalah pribadi dari kelompok 3

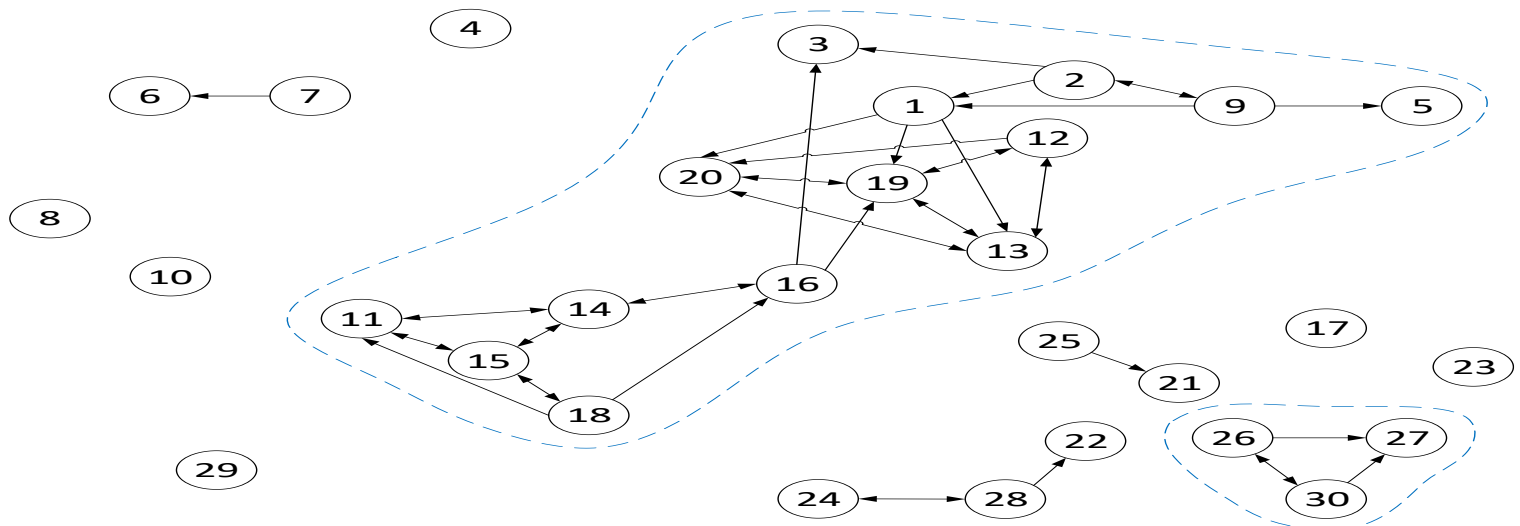

Sosiogram 14. Interaksi tentang pembahasan masalah pribadi dari kelompok 4

(15)

16

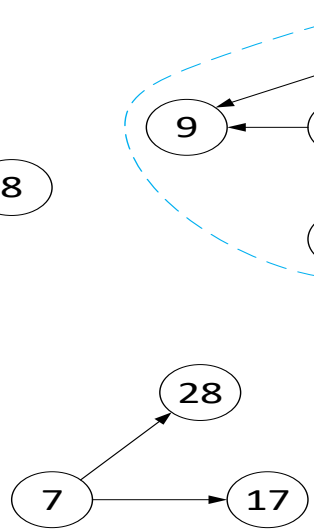

25
1 )

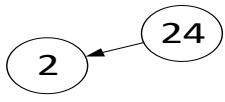

21

20,27

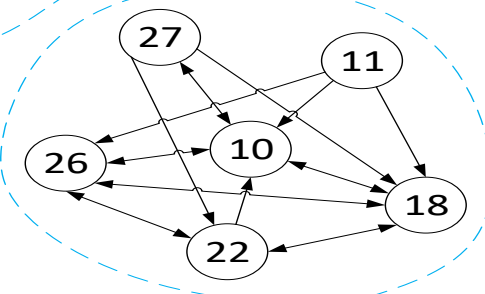

4

6

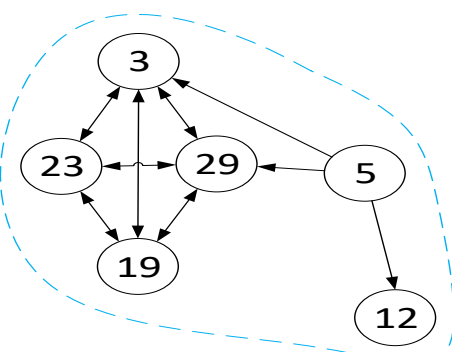


Sosiogram 15. Interaksi tentang hobi dari kelompok 3

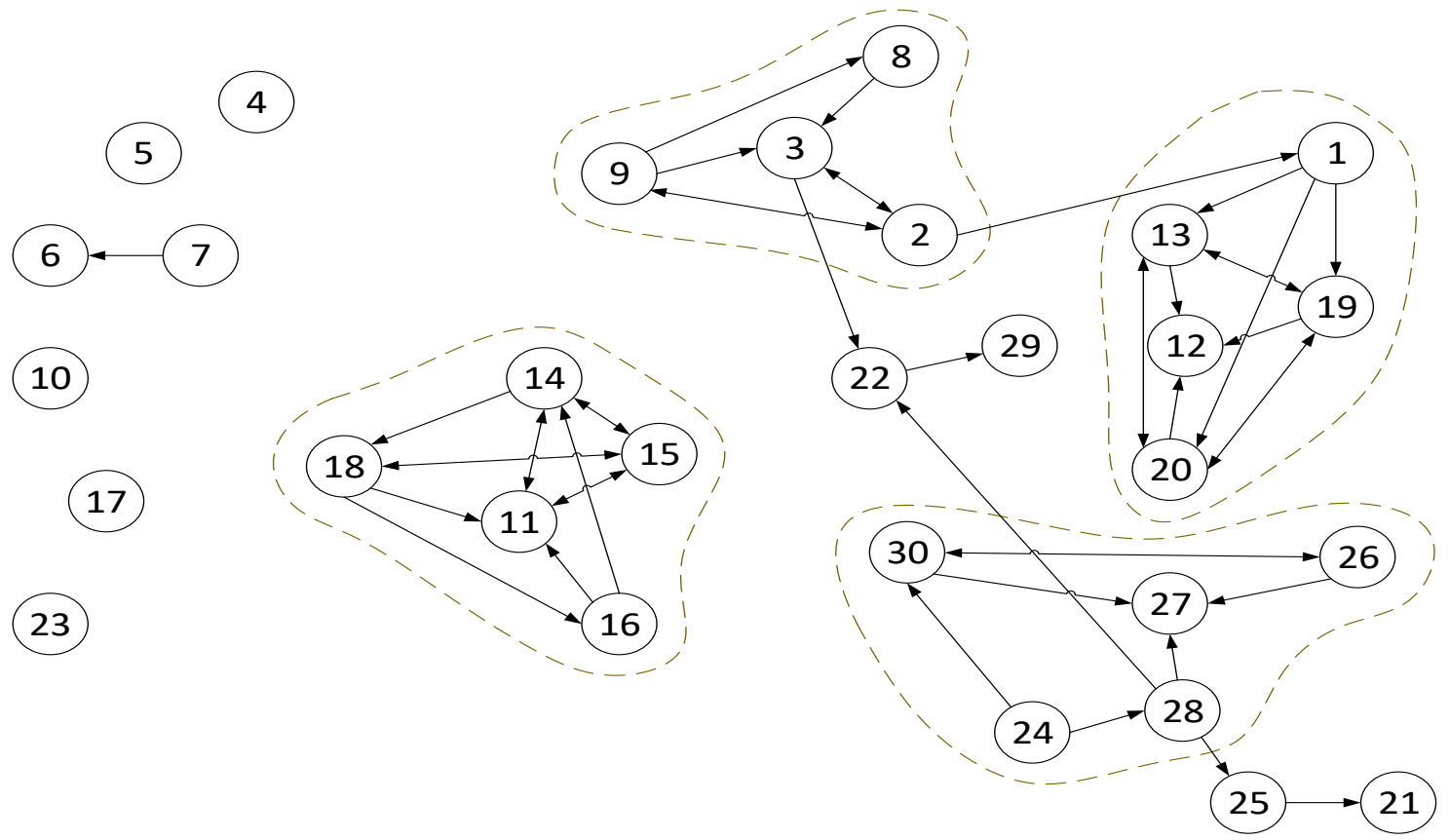

Sosiogram 16. Interaksi tentang hobi dari kelompok 4

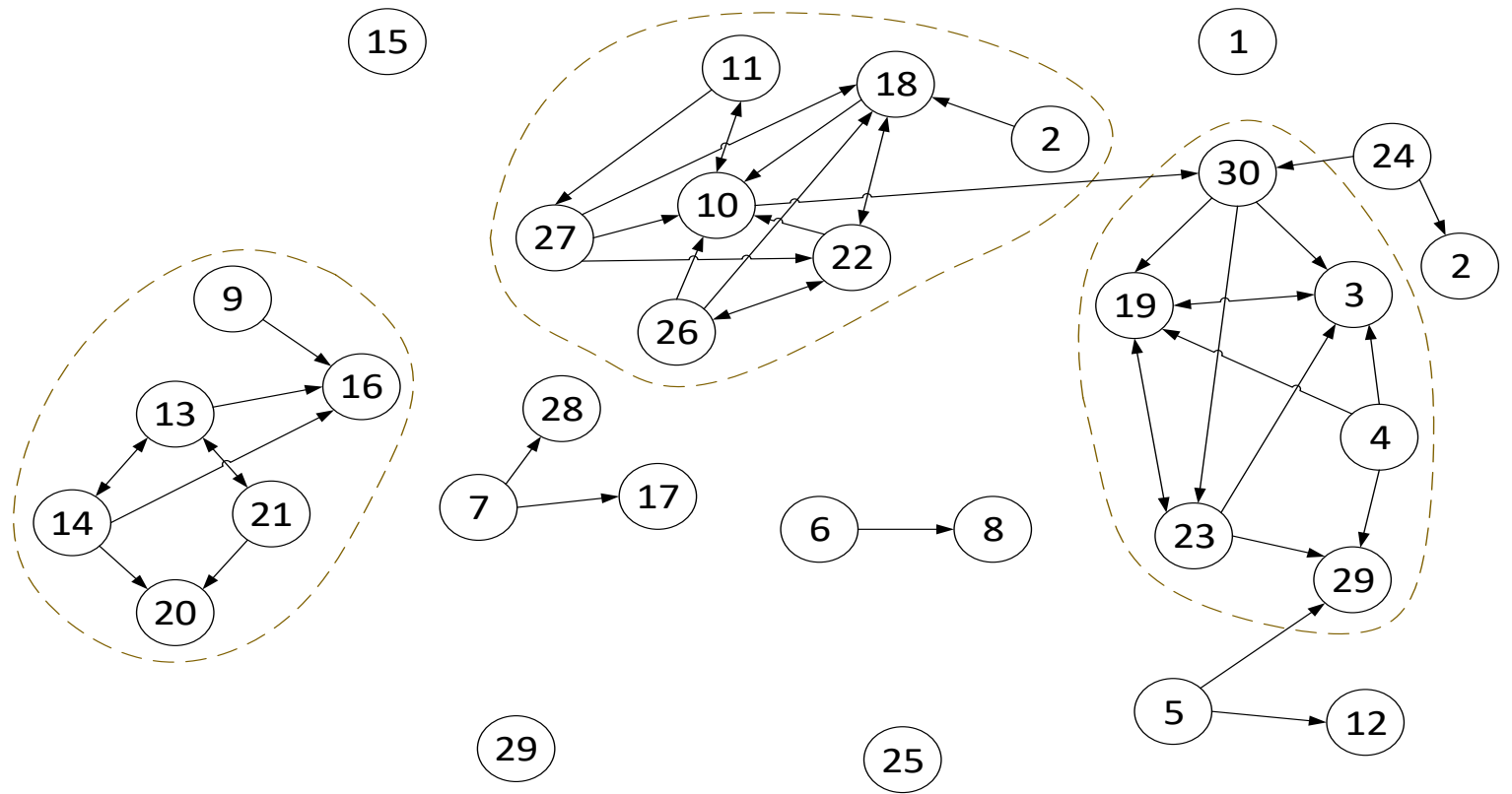

